ISBN:978-81-933894-1-6

International Conference on Arts, Social Sciences, History And Interdisciplinary Studies

(ASSHIS-2017)

Kyoto (Japan), April. 20-21,2017

\title{
The Quality of Education in Border Areas East Indonesia
}

\author{
Heni Ismiati ${ }^{1}$, Randi $^{2}$ \\ ${ }^{1}$ Department of Sociology, Faculty of Social and Political Sciences, Universitas Padjadjaran and \\ awardee LPDP, heni.ismiati16102014@gmail.com \\ ${ }^{2}$ Department of Sociology, Faculty of Social and Political Sciences, Universitas Padjadjaran and \\ awardee LPDP, randy.iboe@gmail.com
}

\begin{abstract}
This research aims to find out how the quality of education in border areas in Indonesia especially in east Indonesia. Papua province is a region of east Indonesia that has lower APM (30.05\%) than other areas. Education is the main thing in the construction area, and every child has the right to have quality of education. Through, strategy and planning Ministry of Education and Culture (Kemendikbud) attempts to let equalization of education by all citizens no exception on the children in undeveloped areas. Bappenas noted by 2015 there are 165 of 412 districts includes undeveloped and poor areas. While, the condition is APK primary education in 2012-2013 has been above 100\%, there are still many problems in terms of equalization either side of spatial or the level of the economy. From the spatial side there are 146 regencies and cities (29.4\%) still have APM SD below 95\%, while there are 169 districts/cities (34\%) still have the APK SMP under 95\%. Durkheim said that education is a social fact. Education can change structure and social mobility for individual status (Durkheim, 1956). It needs educational mapping based on the geographical location, social environment, economic conditions, the condition of the infrastructure, capacity in human resources, political power in the region, how decentralization, also required the application cluster in arranging and placing the appropriate education map. This paper attempts to explain how the fulfillment of education to children in undeveloped areas to see educational mapping in that area. Method of data collection applies literature review, according to the principal problems is examined.
\end{abstract}

Keywords: education quality, border areas, and social change

\section{Introduction}

The border area is a central country defense. An area that is categorized as the border has the characteristic of inland typology (Sutaryo, et al, 2015). There are 26 districts in Indonesia which directly verge with neighboring countries. The Government recognizes that the conditions of management in the border areas still encounter problems. In a re-planning border areas, which has been highlighted by the government is the problem in Kalimantan and Papua (Prasetyo, 2016). According to Bappenas data showed that the amount of undeveloped areas in Indonesia in 2015 was 165 districts out of 412 districts in 34 provinces. When it is compared to the data in previous year, it has reduction in the amount of undeveloped areas in Indonesia, in the previous year, 2014, the number of underdeveloped areas in Indonesia were 183 districts, means that for one year it had reduction of 18 areas included in the characteristics of underdeveloped areas.

Based on data mentioned above, Papua is the east region of Indonesia which verge with neighbour countries and included in the category of undeveloped areas. Regulation of the President of the Republic Indonesia Number 131 Year 2015 regarding the determination of undeveloped areas in 2015-2019 stated that in article 1, 
subsection 1, undeveloped areas are the districts region that its area and society are less developed than other areas on a national scale. Article 2, subsection 1, an area designated as undeveloped regions based on the following criteria: a) the social economy; b) human resources; c), facilities and infrastructure; d) the ability of local finance; e) accessibility; f), the regional characteristics.

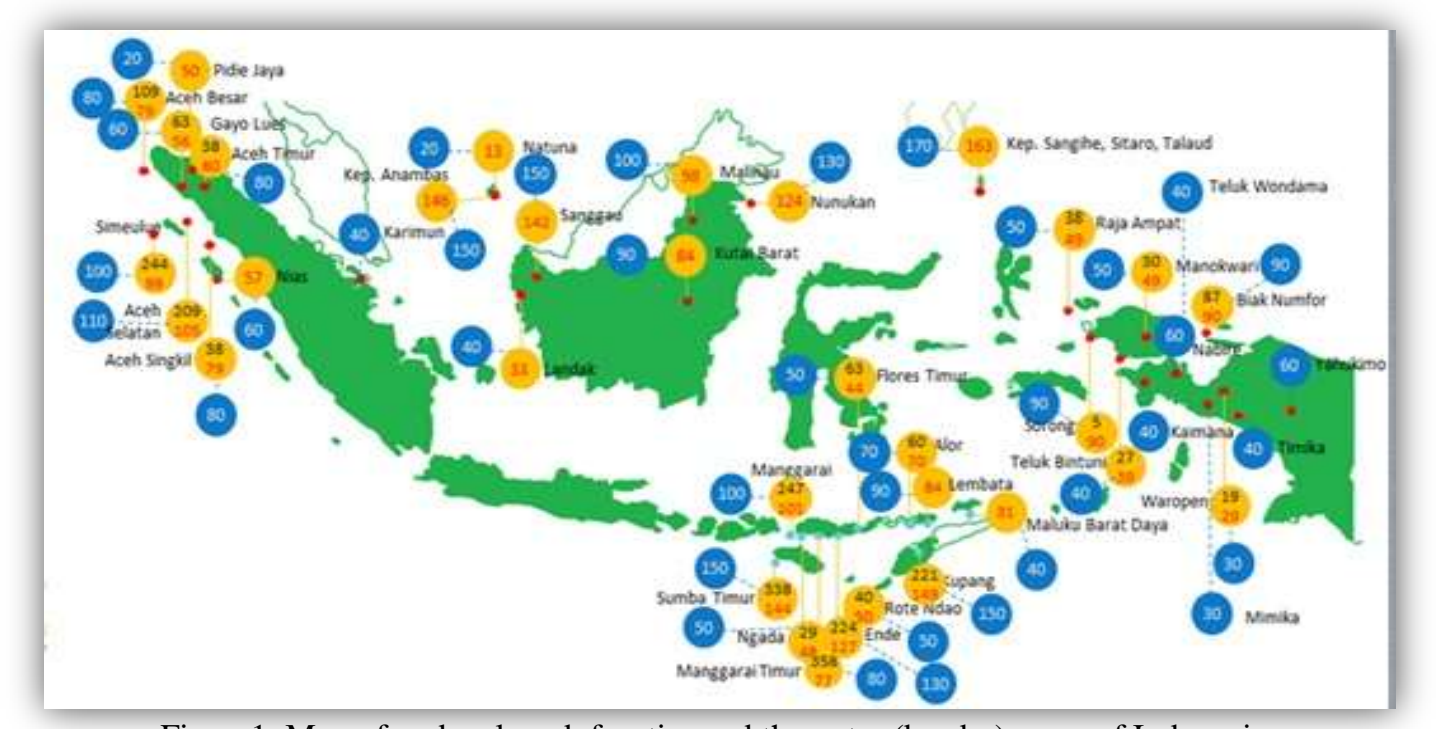

Figure1. Map of undeveloped, frontier and the outer (border) areas of Indonesia

Source : BPS, in www.infogtk.com.

The qualities of human Resources is shown by the quality of education. This will open a variety of opportunities to increase the standard of living and welfare of the community. Early Childhood Education Institutions Non-Formal and Informal (PAUDNI), stated that there are about 800 thousand children drop out of school in east areas of Indonesia. In addition, it also has a high illiteracy rate (Qurays, 2015). Percentage of the population with the highest illiteracy by 2015 is reffered to the provinces in east areas of Indonesia, namely Papua (29.17 percent), and West Nusa Tenggara (13.03 percent). In Papua, the development of education is still very alarming. The Data from the Central Statistics Agency (BPS) showed that more than $50 \%$ of children in school age (3-19 years) do not get education in schools. The following data is APS (School Enrolment Rate) of Indonesian people:

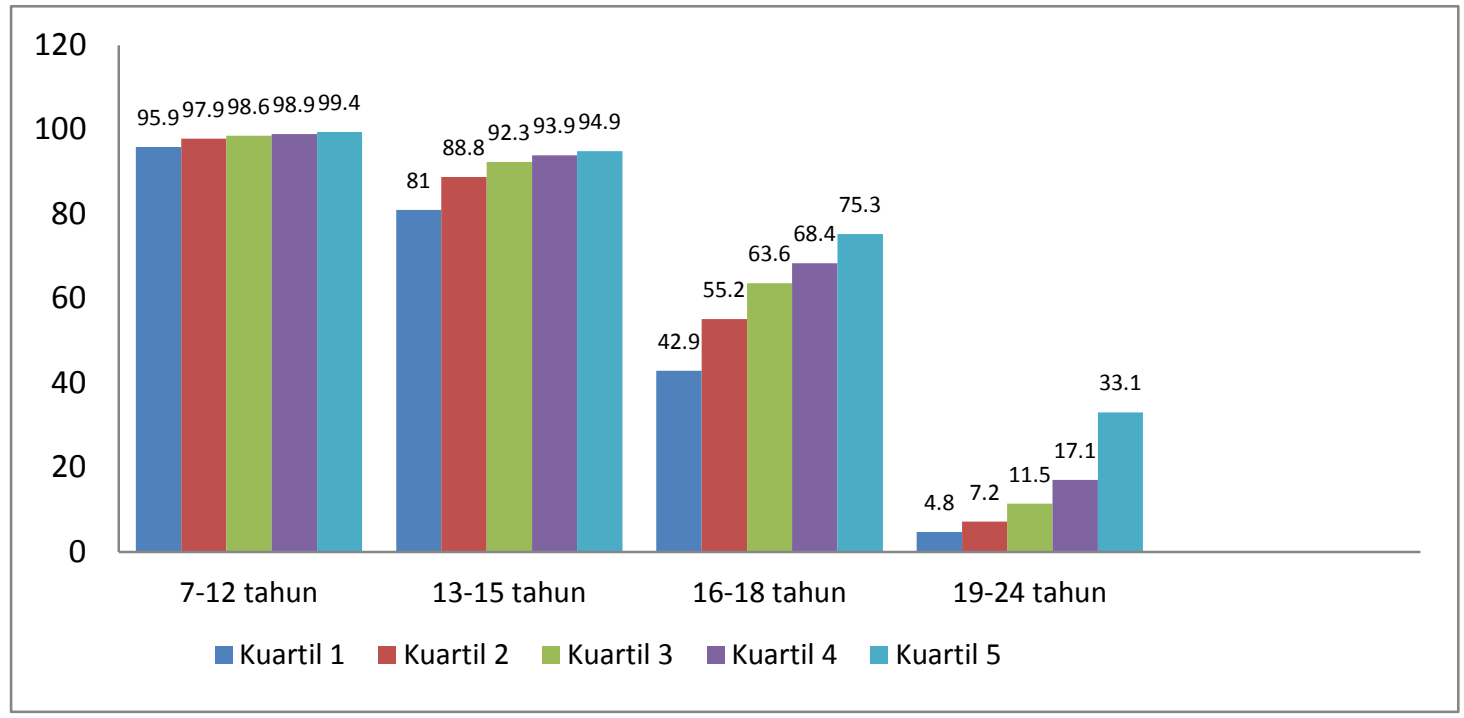

Diagram 1: "APS People Age Group of 7-24 Years by Family Expenditure 2012".

Source: Susenas, BPS. 
Learning quality problem in Indonesia is still not good considered. This is measured by the learning process or student learning outcomes. Various studies have showed that the learning process in the classroom basically does not run interactively, therefore it cannot foster creativity, critical and analytical skills of the students.

The data above does not include the field data related to the condition of schools and availability of teachers to measure standard of graduation set by the central government. According to research conducted by Wismayanti and Noviana (2011), the problems of education for children in the border area showed the low fulfillment of the right of children education. Most of the children are dropped out of school at the primary level. Education facilities also be a crucial factor.

Huruswati, Indah, et al (2010) in their research indicated that the motivation of children in border area concerning education cannot be separated from the willingness and ability of their parents and community towards the importance of education. The border area has a complexity of its own problems, especially in remote areas. Lack of education in the border area occurs because of problem of effectiveness, efficiency and standardization of teachers (Suwanto, 2013).

Based on the data above, the quality of education in the border areas needs serious attention. The extent of the Indonesia geographic regions should be managed properly. It required qualified human resources to advance the frontier regions. Therefore, this paper aimed at examining how the quality of education of children in the border areas, especially in east areas of Indonesia. This research employs a descriptive qualitative research approach. The data collection technique applied the study of literature. The method of this research used the source triangulation. Resources obtained from articles of journals, books, documentation, internet sources and library research. Triangulation resources were required to support the analysis of the study. Articles of the journals and data from the Internet resources, especially from government websites are a main part in the process of triangulation in order to negate the error of data analysis and results. The research objective is to map the situation and condition of the fulfilment of children education in terms of quality in Indonesia border area.

\section{Findings and Discussion}

\subsection{Quality of Children Education in Border Area}

The quality of children education is an inseparable part of the plan of government policy through regional autonomy. Decentralization allows for each region strive to increase regional development and self-reliance in developing the areas including how to design regional autonomy granted by the central government in the field of education. Additional value of educational autonomy according to Hartono (2014) is the independence of the human resources in the area, both in terms of managing the education and local communities. So that people can feel the results of the development of education in their area that are suitable with local needs and conditions.

In terms of the quality of children education, parents are decisive factor, because the decisions on household expenditure on children education is based on the parents' decision (FIP-UPI, 2007). It means that the quality of children education depends on the school or educational institution chosen by their parents. Meanwhile, according to Saifuddin (2014), the quality of children education depends on what is available and provided. Available in the area and provided by qualified teachers or educators. Educators, in this case, play an important

role. The quality of children education is not merely how the quality of teachers and parents' financial capability, but the quality of children education is also manifested in how the children can get guarantee facilities, security and convenience in education (Sumardi, 2005). Furthermore, according to Ali (2009) the quality of education is suitable with the national standards set by the central government that is listed in the Indonesian Government Regulation No. 32 Year 2013 on Amendment of Government Regulation No. 19 Year 2005 on National Education Standards that in article 2, subsection 1 stated, the scope of national standards include content standards, process standards, competency standards, standards of teachers and education personnel, standards of facilities and infrastructure, management standards, standards of financing, and standards of education assessment. 


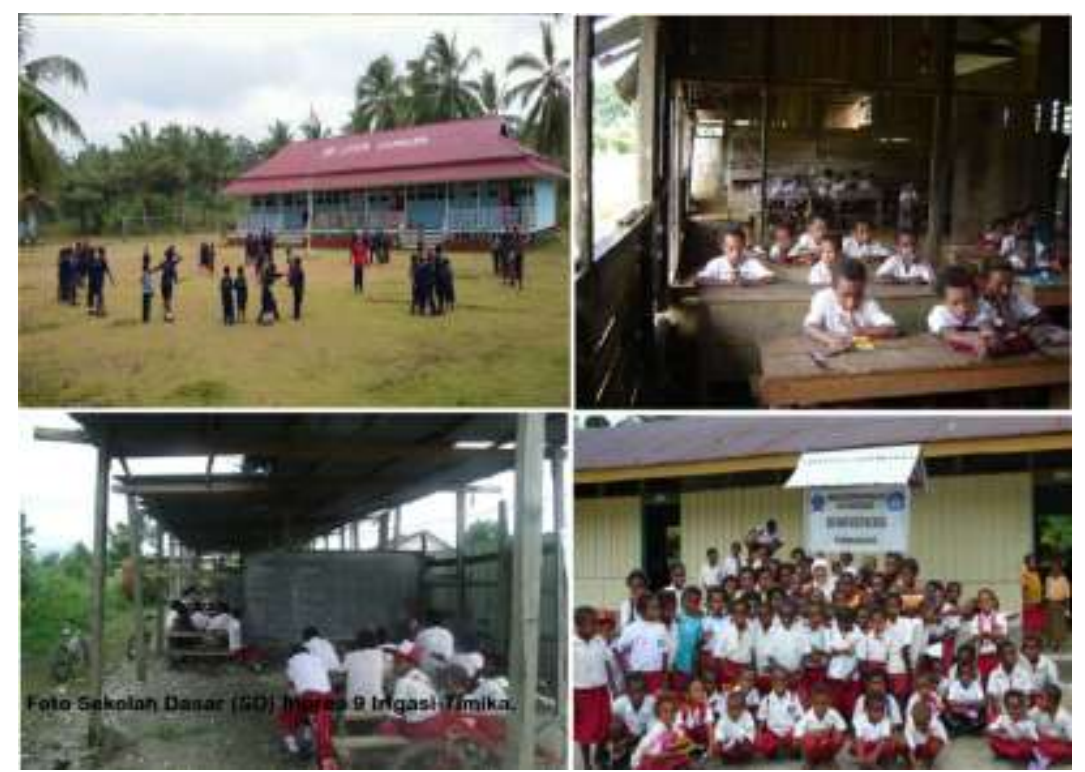

Figure2. Quality of Children Education in Border area of East Indonesia Source: processed picture from SM3T Indonesia

From the picture above showed that education in the border areas like Papua is far from the fulfillment of the quality of facilities and infrastructure. Supporting learning infrastructure of students in elementary school is still very low from the standards have been standardized by the BSNP (National Education Standards). According to the theory of geographic determinism stated that geographical conditions cause differences in the quality of children education in a particular geographic region (Adiwikarta, 2016). Indonesian border regions constitute areas that have at least six indicators as fundamental problems of underdeveloped areas, namely the issue of the economy (people poverty), unqualified human resources, infrastructures, capabilities or the financial strength of limited area, the minimum accessibility to reach the centers of basic services, and the characteristics of areas are prone to social conflicts and natural disasters (Muhtar et al., 2011). This what causes the distribution of education to achieve quality of children education was hard done by the government, and it should be provided with a special standard of education quality provided by the government to the areas included into the undeveloped, the frontier, and the outer (border areas) of Indonesia.

Law No. 20 Year 2003 about National Education Standards in article 5, subsection 3 states that "citizens in remote or underdeveloped and remote areas and indigenous communities have right to receive special education services". Because the children in remote areas are different in terms of economic, environmental, and social circumstances from the children who study in regular schools, so the special education services is urgently needed. The goal is to encourage and motivate them to study and also to foster their confidence. Special education services are usually organized by foundations / non-government organizations (LSM) / Educational and Government Institution.

Durkheim argued that education is a social fact comes from outside the individual and influence the individual. Education can change the structure and mobility of the individuals to change their social status (Durkheim, 1956). The diverse of geographical structure areas in Indonesia, it needs very long time for the government to meet the quality equalization of children education, especially in the border areas. To overcome this problem, according to Paulo Freire, role of the teachers play a very important role. In this kind of education system, the teachers should be forced to be more creative in performing the role (Adiwikarta, 2016). According to Tilaar (2011) explained that the quality of schools will increase if the teachers have high academic competence. Automatically it will also improve the quality of children education. How teachers can teach the lesson material well, socializing with their surroundings and able to bring a pleasant atmosphere for students. Students will learn a lot from teachers who have high academic competence. 


\subsection{Factors Influencing Education Discrepancy in the Undeveloped, the Frontier, and the Outer (Border) area in Indonesia}

Regarding to Marpaung \& Mirani (2011) the first factor, that affects the education discrepancy in the undeveloped region is the limited access. Second, it is about the curriculum which is not oriented to the characteristics of the children in undeveloped region. The curriculum remains centralized to the national curriculum. Third, it is about communication between parents and children. Fourth, it is the economic problems. Fifth, it is about corrupt government. In the analysis conducted by the Ministry of Education and Culture found that the education discrepancy among areas is the implementation of a policy that is not maximized, the quality factor of teachers is still low proved by several studies showed that the learning process in the classroom has not run interactively. Some findings in the field showed that inadequate education facilities owned by undeveloped areas is obstacle aspects in the process of transfering knowledge to the students. Moreover, the weak curriculum factor, curriculum 2013 is considered not sufficiently studied so the schools in undeveloped areas face the difficulties in the implementation. Curriculum substitution burdens the teachers, because the demands of the new curriculum requires the utilization of IT in the learning process which cannot be carried out by the teachers in the undeveloped region.

The assessment system has been not yet comprehensive and reliable, it is proved by the existence of invalid national exam but lately it is ignored by the ministry of education and culture in the presence of pure national exams and the graduation replaced by the school policy. The use of old data, or long statistics survey bring the accuracy of the donation allocation were obstructed. The discrepancy of children education in the undeveloped, the frontier, the outer (border area) can be seen from several micro aspects:

- Teacher competency

How the teachers can build a role in educating children in the border area has become a very important issue, because the conditions when the teachers learn at university is different from the condition after the teacher teaches at the location of the actual devotion. These competencies include pedagogic competence, professional competence and social competence.

- Transparency of the principal

The principal as an office administrator is responsible in implementing regulations and management of the funds that have been disbursed from the government, also responsible for assisting efforts of the students and teachers in pursuing the fulfillment of such educational facilities such as book learning resources, means facilities of learning, as well as a link interest facilitator if the problem of students learning outcomes occurs so that the parents know and play an active role in the learning process of teaching their children. In the conditions of undeveloped areas, the principal can act as the manager of the school, as a researcher and as an operation coordinator.

- Parents participation

Social participation is very essential in order to meet the quality of children education. Parents as a determinant for children to enroll their children to school or do not enroll their children to school. Many children in the border areas are no longer going to school since they have been capable in counting numbers. In this context, the role of parents is very important. The relationship between parents and school should always be involved. It is very difficult to build partnerships between schools and parents when it has collided with economic conditions. Supposedly, parents should always be given the understanding to provide a flexible time for their children to work. Hence, the school time of the children is not disturbed and time for helping parents is still keep running. 


\subsection{Role of Society, Enterprises and Government in the Fulfillment of Children Education Particularly in Undeveloped Area}

The role of parents is very important as a model for their children. Widyaningsih (2010) mentioned that in traditional society, all activities within the family controlled by parents included the education of the children. Those who are aware of the importance of education will attempt to fulfill their children's education well, such choosing the school, and the facilities in order to support their children education. The problem against the fulfillment of children education in underdeveloped area is a matter of economics. Because there has been a commercialization upon education nowadayas causes parents think many times to send their children to a higher level of education. It encourages the government to provide compensation to the poor families through the programs, namely Family Expectations Program (PKH) which guarantees education fees for children education based on the levels of education. Card of Family Welfare which and Smart Card were recently launched by the government of Indonesia. It is a form of concern for the government stake in the alleviation and fulfillment the children education, especially in undeveloped areas. Government program to promote the achievement of education quality and equation is also performed with the involvement of the family into the education.

In addition, to support the fulfillment of children education in the undeveloped area, the government, in 2010, launched a Bidikmisi program on the level of Bachelor. The government through the Fund Management Institution of Education also has realized the opportunity to children who are categorized into the undeveloped areas with free cost of education in graduate and doctorate level, the existence of special autonomy is expected to fulfill children education of undeveloped area and carry out the equity of education, because they will be agents of change later.

In Restra-Kemendikbud 2015-2019 stated that in the developed countries, the role of industry was shown obviously through the corporation program, financial support for research and scholarship. Even in some countries the role of the industry is an obligation according to the law that governs it. Besides the financial support, an important role of industry is to solve the problems of transition from education to the world of work. The industrialized world can serve as a practice, job training and learn management industry, and a place to broaden the world of work for students. The cooperation between schools and industry must be built based on the willingness and needs of each other. The world of work and industry should be aware that the industry is not going to get ready skilled employee who required based on the expected qualifications, without building a joint education program.

\section{Conclusion}

The quality of children education in the undeveloped, the frontier and the outer (border) areas can be performed by expanding the access, either the chance or the same treatment as some policies such as the abolition of tuition fees, as well as the involvement of parents and children to support participation in education. Undeveloped area is a focused area in its improvement. In an effort to meet the quality of children education the undeveloped area (border), the government has provided opportunities of scholarship for children from the undeveloped areas although it is still not maximized. Therefore, the government through the ministry of education and culture has prepared a development strategy for education 2015-2019, in order to create educational equity and the reduction of the number of underdeveloped areas in Indonesia as well as the fulfillment of the quality of children education in the border areas.

\section{Acknowledgement}

This research was supported by Lembaga Pengelola Dana Pendidikan RI (LPDP) as one of the funding agencies and credible scholarship in Indonesia. And then I has succeeded in finishing this paper and I am gratly thanked to Bintarsih Sekarningrum as my lecture who halped me to finish this paper. 


\section{References}

[1] Adiwikarta, S. Sosiologi Pendidikan. Bandung: PT Remaja Rosdakarya, 2016.

[2] Ali, M. Pendidikan untuk Pembangunan Nasional Menuju Indonesia yang Mandiri dan Berdaya Saing Tinggi. Jakarta: Imtima, 2009.

[3] Durkheim, E. Education and Sociology translated by Sherwood D Fox. New York: Free Press, 1956.

[4] FIP-UPI. Ilmu dan Aplikasi Pendidikan. Jakarta: Imtima, 2007.

[5] Hartono. Otonomi Pendidikan. Jurnal Potensial, 2014.

[6] Muhtar, d. "Masyarakat Desa Tertinggal". Kemensos, 2011.

[7] Saifuddin. Pengelolaan Pembelajaran Teori dan Praktis. Yogyakarta: Deepublisher, 2014.

[8] Sumardi, I. S. Melawan Stigma Melalui Pendidikan Alternatif. Jakarta: Grasindo, 2005.

[9] Sutaryo, et al._Membangun Kedaulatan Bangsa Berdasarkan Nilai-Nilai Pancasila: Pemberdayaan Masyarakat dalam Kawasan Terluar, Terdepan dan Tertinggal. Yogyakarta: Pusat Studi Pancasila UGM, 2015.

[10] Huruswati, et al. "Pelayanan Kesejahteraan Sosial di Desa Tertinggal Melalui Rumah Sosial” . (2010): Vol.04 No. 2.

[11] Tilaar, H. "Manajemen Proses Peningkatan Mutu Pendidikan di Pulau Terpencil: Kasus Peningkatan Mutu SD di Kabupaten Lembata NTT. In N. Akhmadi, Riset Kebijakan Pendidikan Anak di Indonesia " Tanggerang: The SMERU Research Institute, (2011): pp. 239-281.

[12] Wismayanti, Y. F., and Noviana, I. Perlindungan Anak Berbasis Komunitas di Wilayah Perbatasan. Informasi, (2011):203-212.

[13] Widyaningsih. "Persepsi Orang Tua Terhadap Nilai Pendidikan Anak Perempuan Pada Masyarakat Jawa Tradisional”. (2010):Vol.14 No.1

[14] Prasetyo, A. P. "Re-Planning Wilayah Perbatasan Indonesia”. Retrieved from Kemenristekdikti. 17 Juni 2016, $<$ http://ristekdikti.go.id/re-planning-wilayah-perbatasan-indonesia/>.

[15] Qurays, K. "Masalah Pendidikan di Indonesia Timur". 17 Juni 2015. Kompasiana. 17 January 2017, <http://www.kompasiana.com/infotercepatku/masalah-pendidikan-di-indonesia-timur_55817f7f149773a536fb6f20>.

[16] Suwanto, H. "Potret Pendidikan di Daerah Perbatasan". 14 October 2013, <http://www.kompasiana.com/harisuwondo/potret-pendidikan-di-daerah-perbatasan_553023946ea834ff348b45c5>.

\section{Regulation:}

[17] BidangDIkbud. Undang-Undang No 20 Tahun 2003 Tentang Standar Nasional Pendidikan. Jakarta: Kemendikbud, 2003.

[18] Peraturan Presiden Rebublik Indonesia Nomor 131 Tahun 2015 Tentang Penetapan Daerah Tertinggal Tahun 20152019.

[19] Peraturan Pemerintah Republik Indonesia No. 32 Tahun 2013 Tentang Perubahan Atas Peraturan Pemerintah No. 19 Tahun 2005 tentang Standar Nasional Pendidikan. 